\title{
持続可能社会に向けたバックキャスティング型シナリオ作成手法の提案*
}

\author{
和田 春菜*1, 木下 裕介 ${ }^{* 2}$, 水野 有智 ${ }^{* 1}$, 福重 真一 ${ }^{* 2}$, 梅田 靖 ${ }^{* 3}$
}

\section{Proposal of a Design Support Method of Backcasting Scenarios for Sustainable Society}

\author{
Haruna WADA ${ }^{* 1}$, Yusuke KISHITA, Yuji MIZUNO, Shinichi FUKUSHIGE \\ and Yasushi UMEDA
}

${ }^{* 1}$ Osaka Univ. Dept. of Mechanical Engineering

Yamada-oka 2-1, Suita, Osaka, 565-0871, Japan

In the life cycle engineering, describing scenarios is considered a good approach to sustainability in manufacturing in terms of clarifying visions of future manufacturing industry. When envisioning sustainable futures, describing "backcasting" scenarios is especially hopeful, because in a backcasting scenario, ideal future visions are firstly developed apart from the present situation. Although many scenario development methods have been proposed, these methods are too abstract, especially have no specific procedure for designing backcasting scenarios. This paper proposes a method for supporting design of backcasting scenarios using logic trees. In this method, logic trees support determining the structure of a backcasting scenario and creating storylines, which are outlines of sub scenarios. The logic tree and the storylines support describing the scenario text. As a case study, we described a backcasting scenario on "breakdown" of Japanese manufacturing in 2050. The result of the case study revealed that the logic tree systematically supports determining the structure of this scenario and generating its storylines. And composing scenario text is successfully supported by detailing the logic tree and the storylines.

Key Words : Design, Social System Design, Computer Support, Sustainabiliry Scenarios, Scenario Design, Backcasting Scenario, Logic Tree

\section{1. 緒言}

現在の大量生産・大量消費型の製造業は，今後持続可能社会に向けて大きく変革される必要があると考えられ る(1). しかし，製造業や社会がどのように変わっていくべきか，具体的なイメージは不明瞭である．持続可能な 製造業や社会のさまざまなイメージを描くために有効なアプローチとして，シナリオを記述するという方法があ る(2).ここで言う「シナリオ」とは，望ましい，あるいは望ましくない将来の状況と，現在から将来までの一連 の流れを記述したものである ${ }^{(3)}$. 持続可能な社会の将来像を描いたシナリオ(持続可能社会シナリオ)の代表例と して，温室効果ガス排出の展望を記述した IPCC の Special Report on Emission Scenarios ${ }^{(4)}$ や，世界のエネルギーに 関する展望を書いた IEA の World Energy Outlook ${ }^{(5)}$ ，2050 年の日本社会のイメージを描いた 2050 日本低炭素社会 シナリオ ${ }^{(6)}$ などが挙げられる．例えば 2050 日本低炭素社会シナリオは，2050 年の日本において，CO2 排出量が 1990 年比で $70 \%$ 削減された「経済成長重視の将来」と「自然との調和重視の将来」の 2 つの将来像を想定し, そ れらの実現可能性，実現方法を検討したものである．このようにシナリオの中で将来までの一連の流れを考える ことで, 将来の具体的なイメージを描くことができ, またその将来に到達するために必要なことを議論できる.

このようなシナリオの作成や分析を統合的に支援するために，我々は持続可能社会シナリオ(3S)シミュレータ を提案している(2)(7)(8)(9). この $3 \mathrm{~S}$ シミュレータのコンセプトの下で，本稿ではシナリオ作成支援手法を提案する.

* 原稿受付 2012 年 3 月 31 日

*1 学生員, 大阪大学 大学院工学研究科 機械工学専攻 (†565-0871 大阪府吹田市山田丘 2-1)

*2 正員, 大阪大学（干565-0871 大阪府吹田市山田丘 2-1)

*3 正員, フェロー, 大阪大学（广565-0871 大阪府吹田市山田丘 2-1）

E-mail:wada@lce.mech.eng.osaka-u.ac.jp 


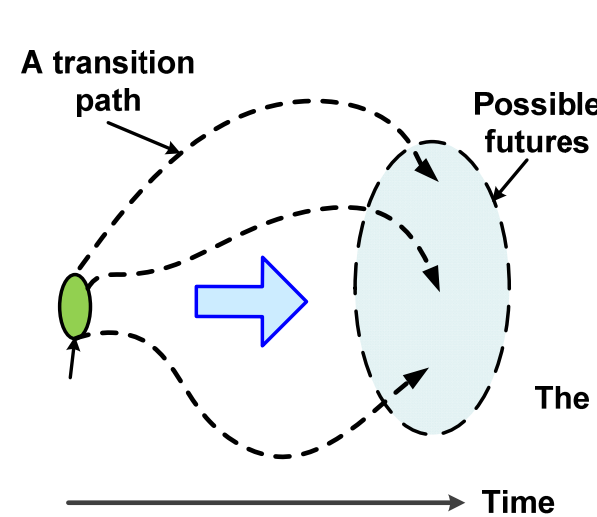

(a) Forecasting

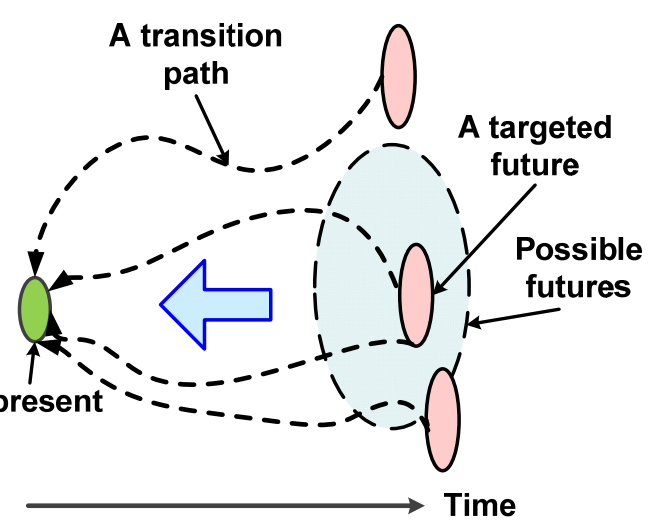

(b) Backcasting

Fig. 1 Images of forecasting and backcasting

一般にシナリオ作成手法は，(a)フォアキャスティング型と(b)バックキャスティング型という2つの型に分類され る(10). 前者は図 1 左部のように現在を始点として将来を探索するもので, この方法で作成したシナリオの例とし ては Special Report on Emission Scenarios ${ }^{(4)}$ やWorld Energy Outlook ${ }^{(5)}$ が挙げられる．この方法は現在の状況を外挿す ることによって将来を描くことができるが，探索して得られる将来は現在の状況に基づくため，現在と全く異な る将来を描くことは困難であると考えられる，一方後者は，図 1 右部のように最初に目標とするビジョンを描き， 次にそれを実現する道筋を将来から現在にさかのぼって記述するもので, 2050 日本低炭素社会シナリオ ${ }^{(6)}$ がこれ に該当する．バックキャスティング型はフォアキャスティング型と異なり，現在の状況を前提とせずに描きたい 将来を定義するという特徵を持つ. このため, フォアキャスティング型では想定できない将来を想定することが でき, 劇的な変化が求められる問題に対して有効であると言われている ${ }^{(10)}$. そこで本稿では, 持続可能社会シ ナリオをバックキャスティング型で作成する手法を提案する.

\section{2. 持続可能社会シナリオの作成}

\section{$2 \cdot 1$ 既存のシナリオ作成手法}

将来を考える手法としては様々な事象や要因の間の複雑な因果関係に基づくネットワークモデルに基づいて将 来をシミュレーションする System Dynamics ${ }^{(11)}$ と呼ばれる手法があり, System Dynamics に用いられるような因果 ネットワークに基づいてシナリオを作成する手法 ${ }^{(12)}$ ，特にフォアキャスティング型のシナリオ作成を支援する 手法が提案されてきた ${ }^{(9)}$.

バックキャスティング型の考え方を提唱した Robinson ${ }^{(13)}$ は，ある定められた将来から現在までの道筋を描く 手法として，バックキャスティング型のシナリオ作成のフレームワークを提案した．そのフレームワークは, (1)シナリオの目的決定，(2)シナリオの目標と制約を設定，(3)現在のシステムを記述，(4)シナリオ外部の前提条 件を特定, (5)将来の記述, (6)シナリオの分析の 6 つから構成される. このフレームワークを直接用いて作られた シナリオは見当たらず，有効性は不明である.

これに対して，手順の一般化はされていないが，バックキャスティング型のシナリオを作成した試みはいくつ かなされている(14)(15)(16). Mander ら ${ }^{(15)}$ は 2050 年までにCO2 排出量を 1990 年比で 60\%削減させるという目標のも とに，イギリスの将来のエネルギーシナリオを描いた。エネルギー需要の満足を制約条件とし，目標である $\mathrm{CO} 2$ 排出削減を達成するためのエネルギー源のベストミックス, およびそれを達成するための技術開発, イン フラ整備のロードマップをバックキャストにより検討した．このシナリオの作成手順は，(1)将来の目標を設定， (2)現在のエネルギー消費や需要のパターンを記述，(3)目標を実現するような将来を複数想定，(4)各将来を実現 するために現在と将来の間に中間の将来をいくつか想定，(5)将来，現在，中間の将来の間を接続するための道 筋を記述，という 5 段階である。.また，Kok ら ${ }^{(16)}$ は長期的な将来の状態を探索する手法と目標達成のための短期 的なアクションを検討する手法の両者を組み合わせて，ヨーロッパにおける水の供給に関するシナリオを以下の 手順で作成した. すなわち(1)シナリオで描くべき範囲を設定, (2)現状分析を行い, 将来不確実な要素を抽出, (3)不確実な要素を元にストーリーを記述して Exploratory scenarios(探索的なシナリオ)を作成，(4)(3)の結果に基づ 
き将来像を設定し，その将来を達成するために必要なものや達成に障害となるものを抽出することでBackcasting scenarios を作成，(5)現状と将来をつなぐため，シナリオからロバストな戦略を決定，という５段階である.

\section{$2 \cdot 2$ 既存のバックキャスティング型シナリオ作成手法の問題点}

バックキャスティング型に限らずシナリオのストーリーは一貫性のあるものでなければならない(12). また，バ ックキャスティング型シナリオの作成においては，現在の状況と独立して将来を想定するだけでなく，その将来 に現在から到達するために必要な道筋を考えることが本質的に重要となる. すなわちバックキャスティング型シ ナリオにおいては因果関係で現在と将来をつなげたストーリーを作成する必要がある. シナリオは何度もレビュ 一を繰り返してブラッシュアップしながら作成するため ${ }^{(17)}$, シナリオ作成過程でシナリオが合理的に理解しや すく, 検証しや寸いことが求められる. また，バックキャスティングの定義上，作成する際には因果的に逆方向 の思考が必ず含まれるが，これは通常の順方向の思考と異なるために困難である. すなわち，バックキャスティ ング型のシナリオ作成方法論には，以下のような要件が考えられる.

(a) 現在から将来まで因果関係でつながったストーリーを記述すること.

(b) シナリオの合理的な理解や検証が行いやすいこと.

(c) 因果的に逆方向の思考が行いやすいこと.

$2 \cdot 1$ 節で挙げた既存のバックキャスティング型シナリオ作成手法においてはフォアキャスティング型のよう な作成支援手法 ${ }^{(9)(12)}$ がない. Robinson のフレームワークではシナリオを作成するための具体的な操作が未定義で ある. また, Mander の方法では目標から将来像を出す際に因果的に逆方向に検討しているが，将来と現在をつ なぐストーリーを記述する方法論が定められていない，Kokの方法論は作成手順は具体的だが，現在と将来をつ なぐストーリーを記述する方法論や，因果的に逆方向に将来を検討する支援がない.

\section{3. バックキャスティング型シナリオの作成手法}

\section{$3 \cdot 1$ アプローチ}

本稿ではシナリオをいかに作成するのかを明確化するために, シナリオの内容を段階的に詳細化していく作成 プロセスを定義する． 2 ・ 2 節で述べたバックキャスティング型シナリオ作成の要件を満たすために，本稿では 以下の 3 つのアプローチに基づいて, 作成プロセスの詳細を定める.

(A) 現在から将来までをつなげるために, 現在から将来まで順方向にシナリオを記述する.

(B) シナリオの合理的な理解や検証が行いやすくなるように, 記述の根拠や記述間の論理的な関係を明確化 する構造的記述法 ${ }^{(7)}$ 用いてシナリオを表現する.

(C) 因果的に逆方向の思考, アイデアの発想を支援するためにロジックツリーを用いて将来の目標達成の流 れを可視化，整理し，それをガイドラインとしてシナリオを作成する.

アプローチ(A), (C)により, 因果的に逆方向の思考を行ったあと, 現在から将来までを順方向で描くことで, 逆方向と順方向の両方向の作業でシナリオを記述寸る. また, アプローチ(C)では, 将来達成したい状態に必要 な手段を洗い出し，出来事や行動とその間の因果関係を整理するために，ロジックツリーを用いる.

\section{$3 \cdot 2$ バックキャスティング型シナリオのモデル化}

本稿ではバックキャスティング型のシナリオを，以下の要素を用いてモデル化する.

(1) 問題: 記述目的, 背景, 記述期間や対象地域など, シナリオ全体の問題. 将来達成したい状態である目 標もこれに含む.

(2) ロジックツリー：目標達成の手段の一連の流れをノードとリンクで表現したもの.

(3) キーイベント：ロジックッリーの要素の中で, 目標達成の仕方を決定づける状態, あるいは出来事を表 す.

(4) シナリオ本文 : 構造的記述法を用いて書かれたシナリオの本文を表す.

(5) ストーリーライン: 各サブシナリオの概要を表す. 


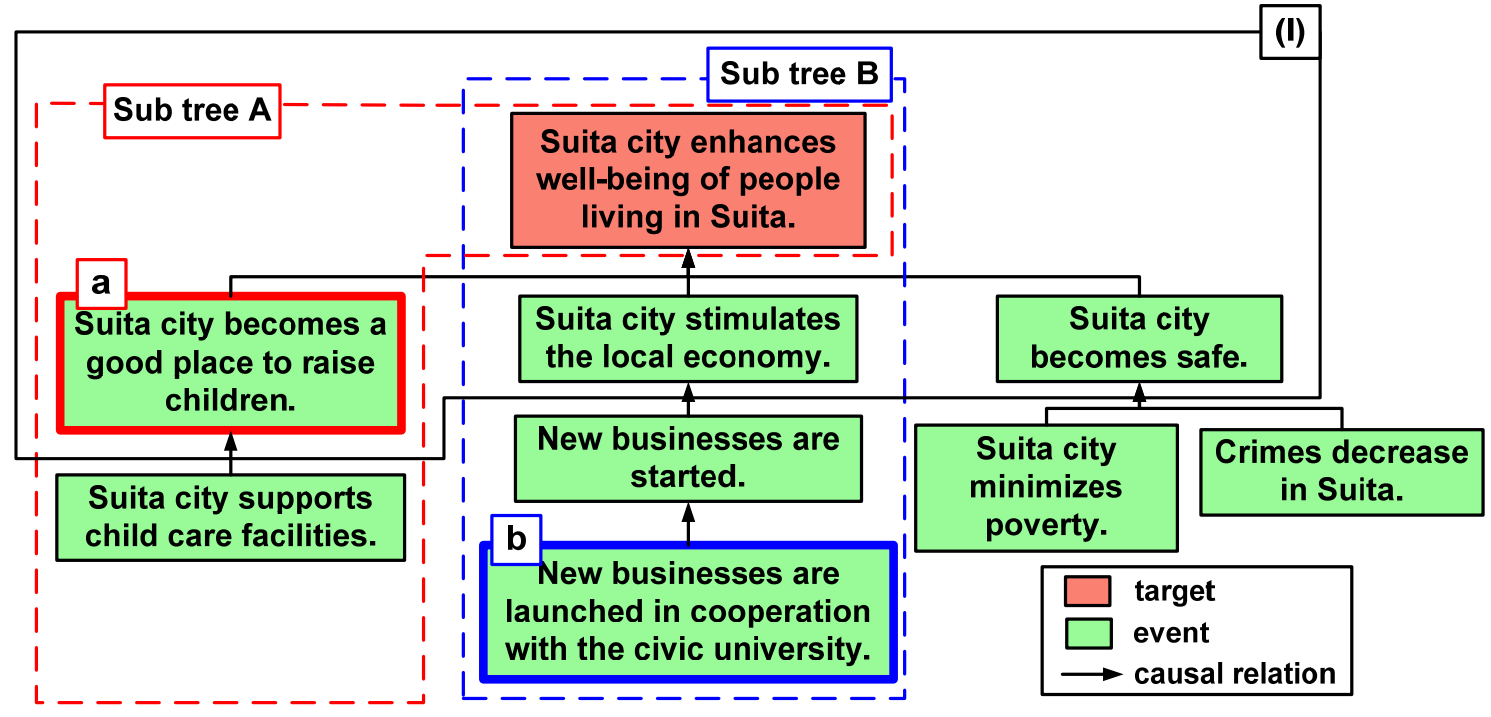

Fig. 2 Example of a logic tree

(6) サブシナリオ：シナリオにおいて，ある特定の達成したい将来(将来像)およびその将来への道筋(移行過 程)について書かれた記述のかたまりを表す，サブシナリオごとに名前，キーイベント，ストーリーライ ン，シナリオ本文内のサブシナリオ相当部分を含む.

本方法論において, シナリオの主要部分である将来像と移行過程は(5)サブシナリオに含むとする. (4)シナリ オ本文のサブシナリオ以外の部分は，問題設定を文章にしたものや，サブシナリオ相互の比較部分，シナリオ全 体の考察や結論, つまりサブシナリオ間で共通の，シナリオ全体に関わる記述とする．ここで，本研究ではシナ リオがどのような内容のサブシナリオをいくつ含んでいるか，ということを「シナリオの全体構成」と定義し， サブシナリオを記述する前に(1)問題設定，(2)ロジックツリーから(3)キーイベント，(6)ストーリーラインを記述 することでシナリオの全体構成を決定する. ここで(2)ロジックツリーと(4)で述べた構造的記述法についてそれ ぞれ $3 \cdot 2 \cdot 1$ 節, $3 \cdot 2 \cdot 2$ 節で説明する.

\section{$3 \cdot 2 \cdot 1$ ロジックッリー}

ロジックツリーは一般的に，物事を論理的に分析・検討する際に，その論理展開を樹形図で表現したものであ る. 結果一原因，目的一手段，全体一部分といった推論を繰り返して論理展開を行うとき，その概念・事象間の 論理的なつながりをツリー状に図示することで，相互関係が明確に把握できるようになる ${ }^{(18)}$.

本研究では, 図 2 のように, 問題設定で決定した目標を始点ノードとして, 上位ノードの原因となる出来事や 必要な状態を下位ノードに記述したツリーであると定義し，ノードとリンクの関係によって目標をどのように達 成するか，目標達成までの一連の流れを表現する，ロジックッリーを構成するノードとして，“target”と“event” ノードの 2 種類を定義する，それぞれの定義は以下のとおりである.

- target: シナリオの目標

・ event: シナリオ内で起きる出来事，およびシナリオ内のアクターが取る行動

また，リンクは，Aが起きれば $\mathrm{B}$ が起きるという因果関係を $\mathrm{A} \rightarrow \mathrm{B}$ というように矢印を用いて表す．図 2 の(I) 部においては，目標「吹田市民の幸福度を高くする」を達成するためには，「子供を育てやすくする」「地域経済 を活性化する」「市を安心・安全にする」という吹田市の行動が必要となるということが，(I)部に含まれる target ノード, eventノード，およびそれらの間のリンクによって表現されている.

\section{$3 \cdot 2 \cdot 2$ シナリオの構造的記述法(7)(8)}

シナリオの構造的記述法は，持続可能社会シナリオの合理的な理解や作成のためのシナリオの表現方法である. ここでは, シナリオをマクロおよびミクロな視点から理解するために, Scenario, Expression, Word, Dataの4つ のレベルで構造化する. Scenario Level はシナリオとサブシナリオ，またサブシナリオ間の関係を, Expression 


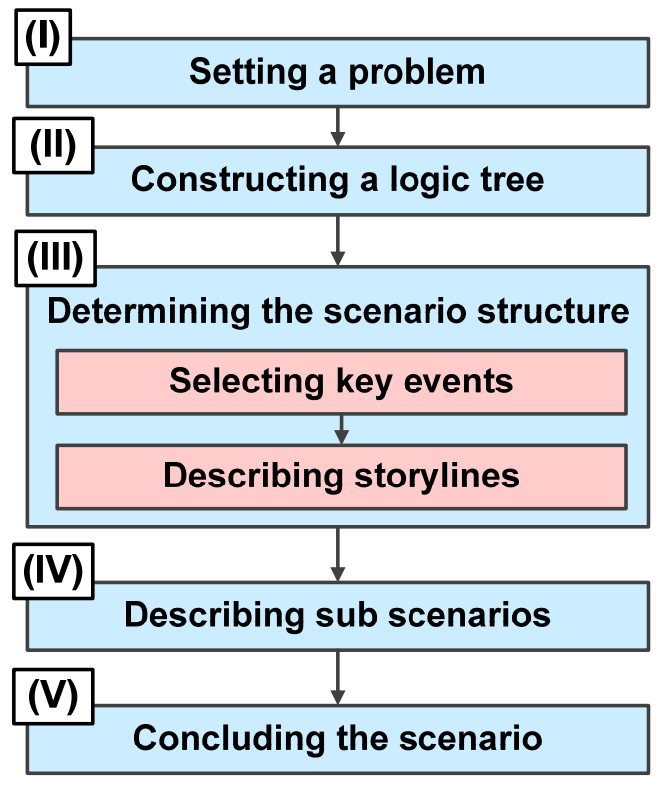

Fig. 3 A design process of a backcasting scenario

Level ではサブシナリオにおいてシナリオ記述における節(clause)の論理構造をそれぞれ表す．Word Level ではシ ナリオに含まれる語句間の関係を表現し，Data Level はシナリオとシミュレータを接続するために，シミュレー ションに用いられるモデル記述とその入出力パラメータを表現する(8). これら各レベルにおいてシナリオの構造 をノードとリンクを用いた有向グラフとして表現する. ノードはシナリオの要素(シナリオ，サブシナリオ，節 など)を, リンクは要素間の関係(包含関係, 参照関係など)をそれぞれ表現する. 構造的記述法を用いて書かれた シナリオの文書を構造化シナリオと呼ぶ.

\section{$3 \cdot 3$ バックキャスティング型シナリオの作成プロセス}

本稿ではバックキャスティング型のシナリオを，(I)問題設定，(II)ロジックツリーの構築，(III)シナリオ全体構 成の決定, (IV)サブシナリオの記述, (V)シナリオ全体のまとめの 5 段階で, 徐々に内容を詳細化して作成する (図 3 参照).

はじめに，どのようなシナリオを作成するかということを決めるために問題設定を行い，この段階でシナリオ の目標を定める. 次に, 目標から因果的に逆方向にロジックッリーを展開することで, 現在の状態と切り離して 目標が達成された望ましい, あるいは望ましくない将来の状態と, そこに至るまでの移行過程の骨格となる事象 の流れを整理する，この情報を元に，シナリオの構成を決定する．ロジックツリーで目標達成までの一連の流れ を記述しているが，これでは目標達成に必要な状態間の因果関係しか表現できていない，そこで，現在の状態や 目標を達成することによる副作用, 目標達成の障害となる事象, 目標達成に必要な状態間の相互作用など, ロジ ックツリーで表現できなかった内容を含めてサブシナリオに記述する，サブシナリオの記述では，目標に到達す るか検証するため, 現状から将来までを順方向に記述する. 寸なわち, ロジックッリーを因果的に逆方向に展開 し，各サブシナリオを順方向に記述することで，両方向でシナリオを作成する.

\section{$3 \cdot 3 \cdot 1$ (I) 問題設定}

まず，シナリオの問題設定を行う。ここでは, シナリオを作成する目的(objective), シナリオの中で達成した い目標(target)などを明記することでシナリオ作成者の思考を整理し，シナリオ全体の方向付けを行う．特にバッ クキャスティング型シナリオ作成では，シナリオで達成すべき目標を定める.この目標を, 将来像と移行過程を書き 始める出発点とする. シナリオの問題設定において決定する項目はシナリオを作成する目的やシナリオで達成すべ き目標，シナリオの主人公にあたるメインアクターなどであり，シナリオ作成者は問題設定を通じてシナリオの 記述対象を整理, 明確化できる. 過去の文献, 既存のシナリオなどを調査し, 問題設定で決定する項目を表 1 の ように定めた．決定した問題設定の各項目は，作成者がシナリオ本文に記述する. 
Table 1 A problem of a scenario

\begin{tabular}{|c|c|c|}
\hline \multicolumn{2}{|c|}{ Item } & Description \\
\hline \multicolumn{2}{|l|}{ Title } & Title of the scenario e.g. Manufacturing collapse scenario \\
\hline \multirow{2}{*}{\multicolumn{2}{|c|}{ Objective }} & Objective for describing the scenario \\
\hline & & e.g. Envision catastrophic future of Japanese manufacturing industry \\
\hline \multirow{4}{*}{\multicolumn{2}{|c|}{ Target }} & The future condition must be achieved in the scenario. \\
\hline & & e.g. Japanese manufacturing industry breaks down \\
\hline & & - Unable to keep employment in Japan \\
\hline & & - Unable to keep the level of living standards in Japan \\
\hline \multirow{2}{*}{$\begin{array}{l}\text { Time } \\
\text { horizon }\end{array}$} & Start year & Starting year of the scenario e.g. 2010 . \\
\hline & End year & End year of the scenario e.g. 2050 \\
\hline \multirow{2}{*}{\multicolumn{2}{|c|}{ Region }} & Targeted region in the scenario \\
\hline & & e.g. The region related to Japanese manufacturing industry (i.e. All over the world) \\
\hline \multirow{2}{*}{\multicolumn{2}{|c|}{ Main actor }} & Organization, group, or individual as a main character in the scenario \\
\hline & & e.g. Japanese manufacturing industry (including maintenance services) \\
\hline \multirow{2}{*}{\multicolumn{2}{|c|}{ Actors }} & Stakeholders involved in the scenario besides the main actor \\
\hline & & e.g. Consumers, foreign countries, energy industry etc. \\
\hline
\end{tabular}

\section{$3 \cdot 3 \cdot 2$ (II) ロジックッリーの構築}

このステップでは，シナリオの将来像とそこに至る道筋を描くために，問題設定で設定したシナリオの目標か らその目標の達成に必要な出来事, 状態などを思考, ブレインストーミング, データの収集や分析などによって 挙げ，それを因果的に逆方向に整理することでロジックツリーを構築する．例えば，「吹田市民の幸福度を高く する」という目標を立てた場合, 図 2 のようにその目標から因果的に逆方向に「子供を育てやすくする」「地域経 済を活性化する」「市を安心・安全にする」というように展開することで，この目標を達成するために必要な条件 を洗い出す.

\section{$3 \cdot 3 \cdot 3$ (III) シナリオ全体構成の決定}

目標達成のパターンを表すロジックツリーの一部であるサブッリーに基づいて, シナリオの全体構成を決定す る. そのために, ロジックッリーから目標達成の仕方を大きく決定づけるキーイベントを選択し, キーイベント を含むサブツリーを抽出する，このサブツリーに含まれる event ノードの内容からストーリーラインを作成す る.

(1) キーイベントの選択

サブシナリオで記述する大まかな内容を決定するために，サブシナリオ 1 つに対して 1 つのキーイベントをロ ジックツリーから選択し，目標のノードからキーイベントを通って，ロジックツリーの端点までのノードとリン クを全て取り出すことでサブツリーを抽出する．このサブツリーごとにサブシナリオの名前を決定する．シナリ オ作成者はこの操作を通じてサブシナリオで描きたい内容を決定し, 次の操作でストーリーラインを作成する. 例えば図 2 のようなロジックツリーでは，a「子供を育てやすくする」と b「大学と連携してビジネスを興す」を 吹田市の将来の方向性を決定づけると考え, それぞれキーイベントとした. これによって目標からキーイベント を含むサブツリーが A, B と 2 つできる. このサブッリーから，例えばサブッリーA を含むサブシナリオを「子 育ての町吹田サブシナリオ」と名づける．このようにロジックツリーをキーイベントによって分節化することで, シナリオに含めるサブシナリオの数を決定する.

(2) ストーリーラインの作成 


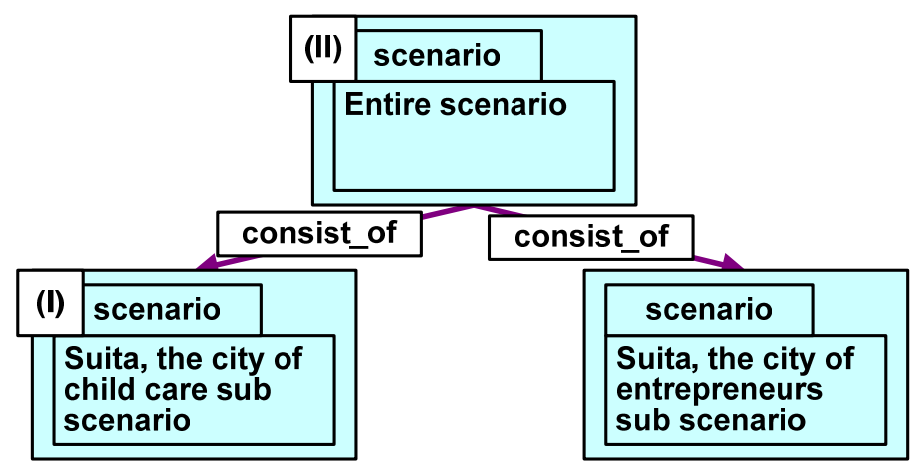

Fig. 4 Example of the scenario structure represented by Scenario Level

ここでは，先ほど抽出したサブツリーから，シナリオ作成者がサブシナリオに書く内容を整理し，理解するた めにサブシナリオの骨子であるストーリーラインを作成する，ストーリーラインを作成することで，この後のサ ブシナリオの記述を実行しやすくなる.

サブシナリオごとにサブツリーを末端ノードから因果的に順方向にたどることで，サブシナリオの骨子である ストーリーラインを作成する．例えば図 2 の a 「供を育てやすくする」の例では，サブツリーA をたどること で，「保育施設を充実させることで子供を育てやすくし，吹田市民の幸福度を高める」という内容のストーリー ラインを作成することができる，このようにストーリーラインを作成することで，各サブシナリオに記述すべき 内容を明確化する。

以上(1)，(2)を通じて決定したシナリオ構成は，構造的記述法の Scenario Level を用いて，シナリオ記述に含め る. 図 4 においては「(I)子育ての町吹田サブシナリオ」を含む 2 つのサブシナリオが, (II)のシナリオ全体に含ま れることが“scenario”ノード間の“consist_of”リンクによって表現されている. 図4のようにこの方法論におけるシ ナリオ構成はシナリオ, サブシナリオ間の階層構造によって表現される.

\section{$3 \cdot 3 \cdot 4(\mathrm{IV})$ サブシナリオの記述}

ここではサブシナリオで記述すべき内容を描いたサブツリーをガイドラインとして，現状に関する記述や目標 達成の障害となる事象, 目標を達成することによる影響などロジックッリーでは表現されない情報を追加しなが ら，構造的記述法の Expression Level を用いてサブシナリオを記述する.このステップではロジックッリーで逆 方向に導出した状態や行動が実際に目標の達成に結びつくかどうかを検証するため, 現状からサブツリーの内容

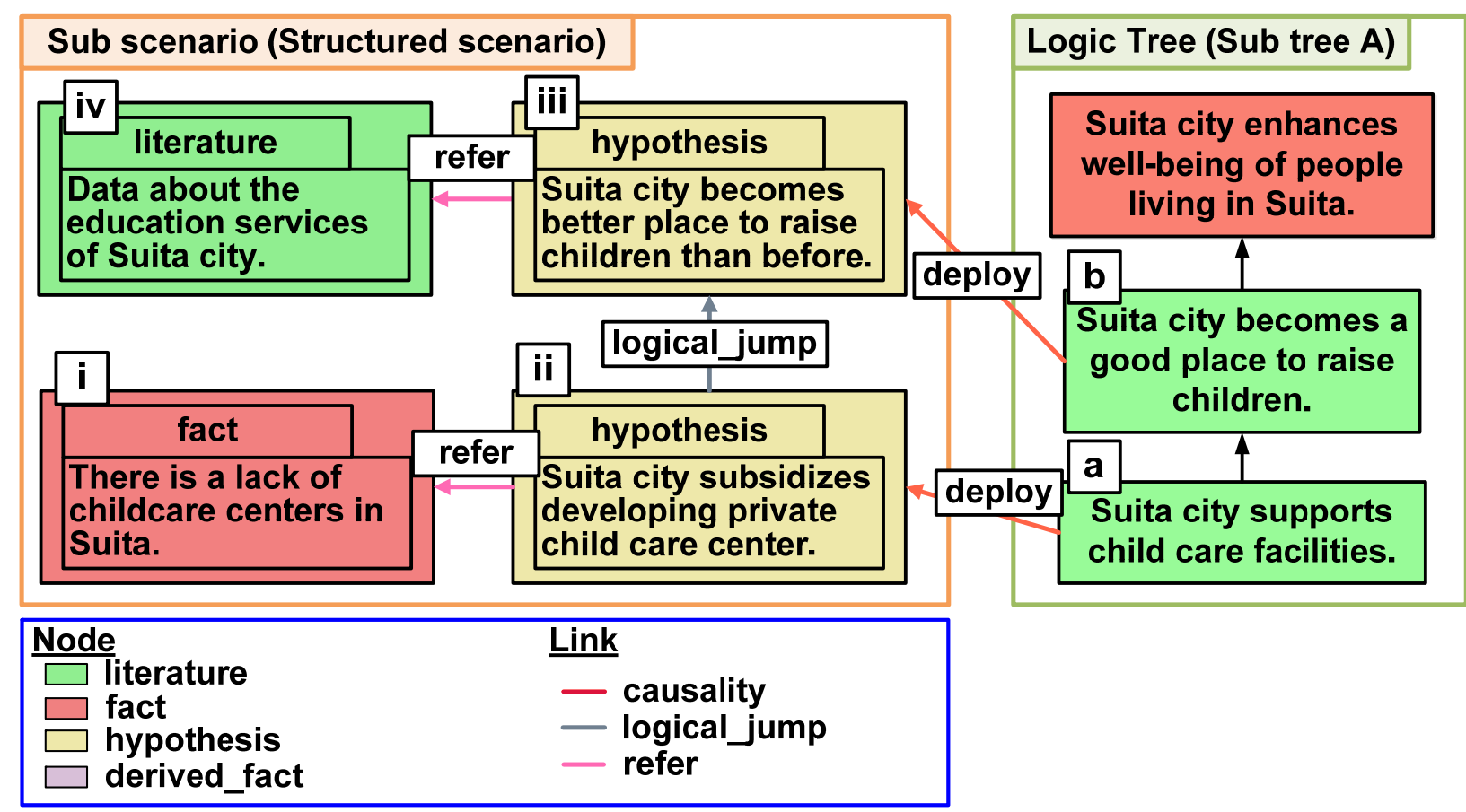

Fig. 5 Example of describing structured scenario 
をガイドラインにして順方向にシナリオを記述する．例えば，図 2 のサブツリーA の一部からサブシナリオを記 述する場合(図 5 参照)，このサブツリーが表現する目標達成の道筋と現状をつなげるために，現状としてi：「吹 田市には保育所が少ない」を記述し，サブツリー内の a ：「吹田市が保育施設を援助する」から ii ：「吹田市は私 立保育施設の設立に補助金を出す」を展開する。このロジックッリー内のノードから Expression Levelノードの導 出関係を表現するために，ロジックツリー内のノードAから Expression LevelのノードBが展開されていること を表す“deploy(A,B)”リンクを定義する，ii はi を根拠とするので，その根拠づけの関係を“refer”リンクで表現する. また，サブツリー内の $\mathrm{a}$ と b：「吹田市は子育てに適した場所になる．」の間の関係から iii ：「吹田市が以前に 比べて子どもを育てやすい場所になる．」という情報を追加し，その根拠としてiv：「吹田市の教育サービスに 関するデータ」を追加する. ii と iii の間には論理的飛躍が含まれるため, 論理的飛躍を伴う導出関係を表す Expression Levelのリンク“logical_jump”で接続する．iiiが ivを参照しているという関係は“refer”リンクで表現する. このように論理関係を明示しつつ，各サブシナリオを詳細化して記述する.

\section{$3 \cdot 3 \cdot 5(\mathrm{~V})$ シナリオ全体のまとめ}

このステップでは，記述したサブシナリオの内容からシナリオの結論を導く．各サブシナリオの結論をまとめ, 各サブシナリオに書かれた状況の相互作用も含めて比較, 分析を行い, シナリオ全体の結論を出し, 構造的記述 法を用いて記述する.

\section{4. バックキャスティング型シナリオ作成支援システム}

本研究では, 第3 章で述ベた方法を実装したバックキャスティング型シナリオ作成支援システムを開発した. システム構成図を図 6 に示す. Scenario Design Manager はシナリオ作成プロセス全体を管理し，各ツール間でデ ータのやり取りを行う。ユーザは Problem Editor で問題設定を行い，そこで設定した目標から Logic Tree Editor でロジックツリーを構築する. Scenario Structure Editor 上でシナリオの全体構成を決定するためにキーイベント を選択すると，自動的にキーイベントを含むサブツリーが抽出される，その内容を元にユーザがストーリーライ ンを記述する. Problem Editor で決めたシナリオの問題と Scenario Structure Editor 上で決定されたシナリオ構成は Scenario Design Managerによって構造化シナリオ，これらの情報を元に作成者は, Scenario Structural Description Support System によって描画された論理構造図(図 5 左部参照)を編集する形で, 構造化シナリオを記述する.

\section{5. ケーススタディ}

本研究で提案した手法とシステムの有効性を検証するためにケーススタディとしてシナリオを作成した. 本ケ ーススタディでは文部科学省科学研究費基盤研究(A)「循環型製造業の将来像を設計するための持続可能社会シナ リオシミュレータの開発」(No. 20246130)で作成した「製造業破綻シナリオ」を取り上げる. これは，持続可能な

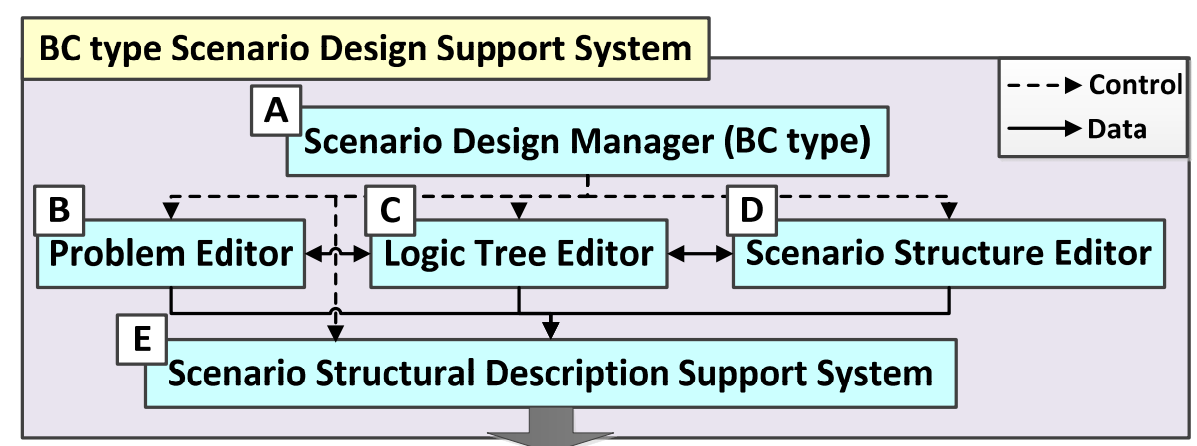

Structured Scenario (XML Document)

Fig. 6 Backcasting (BC) type scenario design support system 


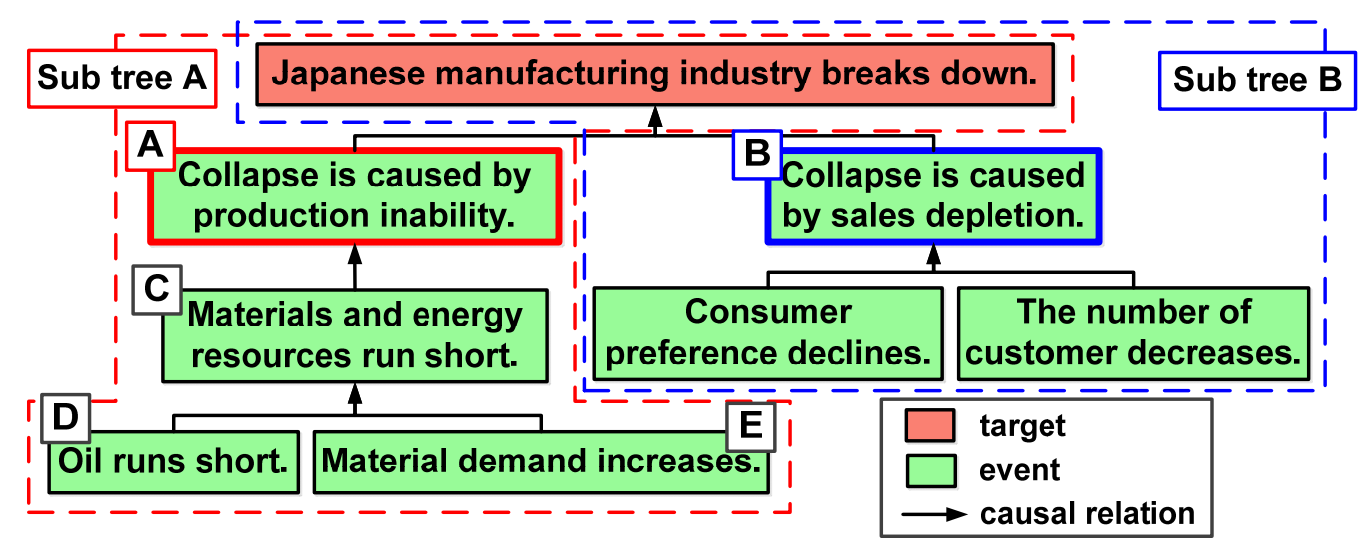

Fig. 7 The logic tree of Manufacturing Collapse Scenario

Table 2 The storylines of Manufacturing Collapse Scenario

\begin{tabular}{l|l}
\hline \multicolumn{1}{c|}{ Item } & \multicolumn{1}{c}{ Storyline } \\
\hline $\begin{array}{l}\text { Resource depletion sub } \\
\text { scenario }\end{array}$ & $\begin{array}{l}\text { Increasing demand of materials causes depletion of copper and runs out. And oil runs out. As a } \\
\text { result of such resource depletion, Japanese manufacturing industry will not be able to produce } \\
\text { or transport their products. This causes the breakdown of Japanese manufacturing industry. }\end{array}$ \\
\hline $\begin{array}{l}\text { Demand decline sub } \\
\text { scenario }\end{array}$ & $\begin{array}{l}\text { Product sales decline all over the world, because the number of consumers decreases and } \\
\text { consumer preference declines, namely, people become negative for consuming. The decline of } \\
\text { demands causes the breakdown of Japanese manufacturing industry. }\end{array}$ \\
\hline
\end{tabular}

製造業の姿をシナリオとして描くための前段階として，長期的に考えたときの日本の製造業の危機的状況，およ びそれをもたらす要因について分析するために作成したものである，上記のプロジェクトの参加者により，提案 した方法論に則ったワークショップを実施し，結果に基づいてシナリオ作成支援システム上でシナリオを作成し た.

\section{$5 \cdot 1$ (I) 問題設定}

本ケーススタディでは，日本の製造業をメインアクターとし，日本の製造業が破綻するシナリオについて問題 設定を表 1 の例のように行った。製造業破綻シナリオでは日本の製造業が破綻するまでの姿と道筋を描く．その ため，このシナリオでは「日本の製造業が破綻すること」を目標とした．ここでの日本の製造業が破綻するとは， 日本の製造業が雇用を生み出すことができなくなり，生活水準が一定以下に下がった状態であるとした．これは 日本の製造業は日本の国民を扶養し，社会にインフラを提供する役割を果たしていると考え，雇用と生活水準と いうパラメータを目標に設定した。

\section{$5 \cdot 2$ (II) ロジックッリーの構築}

問題設定の内容に基づいて「日本の製造業が破綻する」という目標を始点ノードとし，これが達成されてしま う原因となる出来事，行動をワークショップ参加者によるブレインストーミングなどによって挙げた，それを因 果的に逆方向に展開寸ることでロジックツリーを構築した. 構築したロジックツリーを図 7 に示す.

\section{$5 \cdot 3$ (III) シナリオの全体構成決定}

前節で構築したロジックツリーから，製造業破綻シナリオの全体構成を決定した.

(1) キーイベントの選択

ワークショップ参加者でロジックツリーを構築しつつ議論をし， 日本の製造業の長期的な破綻要因を検討する 中で，日本の製造業の長期的な破綻パターンとして，図７のノードA「製品が作れなくなって破綻する」とノー 
ド B「製品が売れなくなって破綻する」の 2 つのパターンを推定し，これらをキーイベントとして選択した．こ のように 2 つキーイベントから図 7 のようにサブツリーA，B を抽出し，これに相当するサブシナリオをそれ ぞれ資源制約シナリオ，需要減少シナリオとし，製造業破綻シナリオは資源制約サブシナリオと需要減少サブシ ナリオの 2 つのサブシナリオから成るものとした.

(2) ストーリーラインの作成

抽出した 2 つのサブツリーを用いて，サブシナリオの骨子であるストーリーラインを作成した．資源制約サブ シナリオに相当寸るサブツリーA で因果的に順方向にノードに書かれているイベントをつなぐことによってスト ーリーラインを作成した，図７のように，サブツリーに含まれるノードD，E，C，Aを目標まで因果的に順方向 につなぐことによって「石油不足や製品材料の需要が増加したことから，資源・エネルギーが枯渇し，製品を作 ることができなくなって日本の製造業が破綻する」というストーリーラインを作成した．需要減少サブシナリオ についても同様にストーリーラインを作成し，まとめたものを表 2 に示寸.

\section{$5 \cdot 4$ (IV) サブシナリオの記述}

このステップでは資源制約シナリオと需要隇少シナリオについてそれぞれサブシナリオ文章を記述した．ここ では例として資源制約シナリオについて述べる.

銅の需要が増えたことによる銅枯渇の危機について記述された図7のサブツリーAのノードE，C，Aの流れか ら，構造的記述法を用いてサブシナリオを記述する例を図 8 に示す.ノード E の「製品材料の需要が増加する」 という内容から，製品材料のうち例えば銅の需要について検討した．このサブッリーと現在の状況をつなぐため に現在の状況として図 8 左部のノード $\mathrm{a}$ 「社会の電化が進んでいる」を記述し，ノード $\mathrm{a}$ とサブッリーのノード $\mathrm{E}$ からノード b「銅の需要が増加する」を記述した． E から b の展開は“deploy”リンクで， a から b の展開は，シナ リオ作成者以外が設定した情報への参照を表す“refer”リンクで表現した．銅の需要が増加したら本当に銅が枯渴 するのかどうかについては銅の長期枯渇予測(19)を参考にして，サブツリーのノード C「材料，エネルギー資源が 枯渴寸る」から，ノード $\mathrm{c} 「 2030$ 年代後半には銅が枯渴する」という記述を構造化シナリオ内に展開した. また， 参考にした情報をノード $\mathrm{d}$ 「銅の長期需要予測」として記述 c から d に“refer”リンクを接続することでこの参照関 係を明示した， d の参照により，銅の需要増加が枯渇の原因であることが明確となったため， bから $\mathrm{c}$ は論理的に 展開し，そのことを両者の間に“causality”リンクを接続することによって表現した．銅が枯渇したらさまざまな

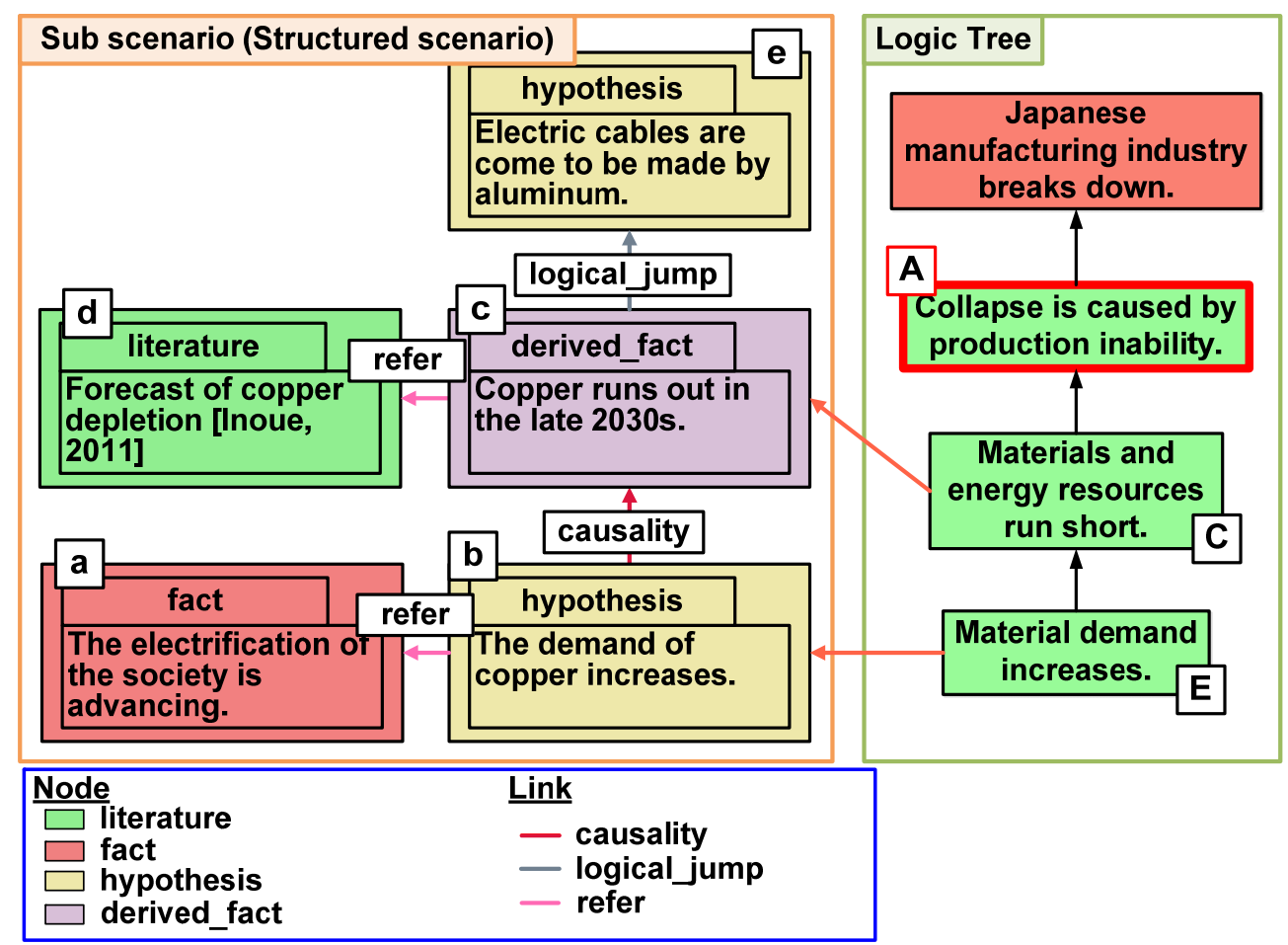

Fig. 8 Structured scenario of Resource depletion sub scenario 
領域に大きな影響を与えると考えられるが，ここでは銅の使途の大半を占める電線に着目して，もし銅が枯渇し た場合には銅の電線を作ることが不可能になると考えた。しかし，現在アルミニウムによる電線の技術開発がな

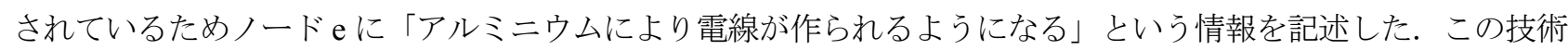
が実用化されてアルミニウムで電線が作られれば，アルミニウムは資源枯渴性が低いために製造業が破綻に向か わない可能性も出てくる，このように，ロジックツリーで因果的に逆方向に展開していたときには想定できてい なかった状態を記述することができた.

\section{$5 \cdot 5(\mathrm{~V})$ シナリオ全体のまとめ}

製造業破綻シナリオ全体のまとめとして，2 つの異なるサブシナリオの結論を考察，分析してシナリオ全体の 結論を以下のように導出した.

“全世界では「需要減少サブシナリオ」は「資源制約サブシナリオ」の後に起こると考えられる．日本国内では 「需要減少サブシナリオ」のような状況がすでに起きているが，需要減少のような状態が起きても，日本の製造 業が世界に出て製品を売れば問題はないと言える．よって，日本の製造業にとって資源制約サブシナリオのよう な状況が最も本質的であると結論づけた．日本の製造業は近い将来起こりうる資源制約を考慮して，使用する資 源を少なくしたり，リサイクルの量を増やしたりしながら持続可能性を高めていく必要がある。”

\section{6. 考}

本稿で提案した手法により，バックキャスティング型のシナリオを新規に作成することができた．また，目標 からロジックッリーを構築し，そのロジックッリーからシナリオ全体構成，ストーリーラインを作成でき，サブ シナリオの記述を支援することができた．本方法論の特徴としては以下の 4 点がある.

(1) ロジックツリーを用いた因果関係の逆方向展開支援

(2) ロジックツリーに基づくシナリオの構成決定

(3) 因果関係の逆方向展開と順方向展開の組み合わせ

(4) ロジックツリーをガイドラインとして用いたシナリオの記述支援

以下，各特徵について考察する.

(1) ロジックツリーを用いた因果関係の逆方向展開支援

ロジックッリーを用いることで，目標から因果的に逆方向に目標達成に必要な状況を考える支援ができた．こ れは, ロジックッリーといら視覚的な要素を整理することによって, 通常の思考とは異なる因果関係の逆展開が 行いや寸くなるからだと考えられる. 一方, ロジックッリーの構築によって目標達成の可能性を網羅的に検討で きるかどうかは，現在は作成者の能力に依存している.

(2) ロジックッリーに基づくシナリオの構成決定

このロジックツリーに基づいてシナリオの内容と構成を決定する部分，すなわち目標達成を大きく決定づける キーイベントの選択は，現在シナリオ作成者が手動で行っているものであり，支援がないということが本手法の 課題の 1 つとして挙げられる. キーイベントの選択基準は「目標達成の仕方を大きく決定づけるか否か」であり， キーイベントを計算機で自動的に判別することは困難であると考えられる．しかし，例えばロジックッリー上で 作成者がノードに重みづけをすることで，イベントの重要度を定量的に比較することができるようになり，キー イベント選択の支援が可能になると考えられる. また， ロジックッリー内のリンクに and, or といった論理演算 子を導入し，ノード間の因果関係をより厳密に検討することも，キーイベントをシステマティックに選択する支 援になると考えられる.

(3) 因果関係の逆方向展開と順方向展開の組み合わせ

ロジックツリーを因果的に逆方向に展開し, サブシナリオでそのロジックツリーを順方向にたどってシナリオ を記述したことで，両方向からシナリオを検討する支援ができ，現在から将来までつながった流れが記述できた． ロジックッリーを元に順方向にサブシナリオを記述したことにより，ロジックッリーで逆方向に展開したときに は検討できなかった, 目標が達成できない可能性や目標達成による副作用を記述することができた. 第 5 章で説 
Table 3 Nodes in Expression Level

\begin{tabular}{c|l|l}
\hline Node & \multicolumn{2}{|c}{$\begin{array}{c}\text { Number of nodes in Expression Level } \\
\text { in Manufacturing collapse scenario }\end{array}$} \\
\hline $\begin{array}{c}\text { Nodes in Expression Level deployed from } \\
\text { nodes in Logic Tree }\end{array}$ & 66 & $41.0 \%$ \\
\hline $\begin{array}{c}\text { Nodes in Expression Level not deployed from } \\
\text { nodes in Logic Tree }\end{array}$ & 95 & $59.0 \%$ \\
\hline Total & 161 & $100 \%$ \\
\hline
\end{tabular}

明した例では図 8 のノード $\mathrm{e}$ のよう，目標達成のために必要な行動の結果，目標を達成できない可能性がある ことを明らかにできた。

(4) ロジックツリーをガイドラインとして用いたシナリオの記述支援

サブツリーをガイドラインとしてシナリオ本文を記述する支援をしたが，ロジックッリーのノードがどこまで 利用できたかを，ロジックツリー内のイベントから展開した Expression Node の, 全Expression Node に占める割 合により評価した．ケーススタディで行ったシナリオについて検証を行った結果を表 3 に示寸。この結果から， ロジックツリーから作成したノード(図 8 中ではノード b, c に相当)は全 Expression Node のうち「製造業破綻シナ リオ」では 41.0\%(66/161 個)となった。 この結果から，ロジックッリーをガイドラインとして用いてシナリオを 記述できたことが分かる．サブシナリオの記述においては，サブッリーの内容に加えて，ロジックッリーのノー ド間の論理性を補足したり，ロジックツリーにない情報，例えば目標達成した場合の副作用や現状分析などの情 報を記述したりした．また，シナリオ本文に書いた問題設定やシナリオ全体の考察，結論もロジックツリーから 展開されなかったノードに含まれる，例えば，図8においては，現状についての記述(ノードa)やサブシナリオ内 の記述の根拠となる参考文献(ノード d)，ロジックツリー内に含まれる出来事，行動の副作用(ノード e)のように， 全体の $59 \%(95 / 161$ 個)に相当するノードを追加した.

しかし，特に移行過程における将来像の実現可能性の検討において，さまざまなシミュレーションは有効に用 いることが可能であると考えられるが，提案した方法論の中でシミュレーションの実行を支援する手法はない．

これについては, 先行研究( ${ }^{(8)}$ で提案された構造的記述法の Data Level とロジックッリーを関連付けて動的なシナ リオの作成を支援する手法を提案することが，今後の課題として挙げられる.

\section{7. 結言}

持続可能社会に向けたシナリオの構造的記述法を使って，ロジックッリーを用いたバックキャスティング型の シナリオ作成支援手法を提案し，またこの手法を支援するシステムを構築した。 この手法とシステムを用いたケ 一ススタディとして製造業破綻シナリオを作成する中で，目標からロジックッリーを因果的に逆方向の思考で作 成することができた．また，そのロジックッリーからシナリオ全体構成，ストーリーラインを導出することがで き，最終的にそれらをガイドラインとして構造的記述法を用いてシナリオ作成の支援をすることができた.

今後の課題として以下の点が挙げられる. 本研究ではバックキャスティング型シナリオの作成支援手法を提案 したが，シナリオの内容や構成を決定する部分においてさらなる支援が望まれる．サブシナリオの記述において， シミュレーションの実行を支援する方法論の提案も，課題として挙げられる．また，本ケーススタディの製造業 破綻シナリオの内容を元に，この手法を用いて持続可能製造業シナリオを作成すること，また外部の人に手法と システムを用いてシナリオを作成してもらうことが挙げられる.

謝 辞

本研究の成果の一部は, 文部科学省科学研究費補助金(No. 20246130，21・316)の助成を受けたものである. 


\section{文献}

(1) Tomiyama, T., “The Post Mass Production Paradigm," Proceedings of EcoDesign '99: First International Symposium on Environmentally Conscious Design and Inverse Manufacturing, Tokyo, Japan, (1999), pp. 162-167.

(2) 梅田靖, “持続可能社会シナリオシミュレーションの必要性とアプローチ”，エコデザイン 2008 ジャパンシンポ ジウム講演論文集, A12-1，東京, (2008).

(3) 松岡譲, 原沢英夫, 高橋潔, “地球環境問題へのシナリオアプローチ”，土木学会論文集，No.678/VII-19，(2001), pp.1-11.

(4) Intergovernmental Panel on Climate Change, Climate Change 2007: Synthesis Report, Contribution of Working Groups I, II, III to the Fourth Assessment Report of the Intergovernmental Panel on Climate Change (IPCC), Geneva, Switzerland, (2007).

(5) International Energy Agency (IEA), World Energy Outlook 2011, IEA Publications, Paris, France, (2011).

(6) 西岡秀三編，日本低炭素社会のシナリオ一二酸化炭素 70\%削減の道筋，日刊工業新聞社，東京, (2008).

（7）木下裕介, 山崎泰寛, 水野有智, 福重真一, 梅田靖, “持続可能な製造業の実現に向けた持続可能社会シナリオシミ ユレータの開発(第 1 報)一構造的なシナリオ記述に基づく論理構造の分析—”，精密工学会誌, Vol. 75, No. 8, (2009), pp. 1029-1035.

（8）木下裕介, 山崎泰寛, 水野有智, 福重真一, 梅田靖, “持続可能な製造業の実現に向けた持続可能社会シナリオシミ ユレータの開発(第 2 報)—シナリオとシミュレータの接続による動的シナリオの作成—”，精密工学会誌，Vol. 76, No. 6, (2010), pp. 694-699.

（9）水野有智，木下裕介，和田春菜，福重真一，梅田靖, “持続可能な製造業の実現に向けた持続可能社会シナリオシ ミュレータの開発(第 3 報)一フォアキャスティング型シナリオ設計支援手法—”, 精密工学会誌, vol. 78, No.9, (2012), (掲載予定).

(10) Dreborg, K., "Essence of Backcasting,” Futures, Vol. 28, No. 9, (1996), pp. 813-828.

(11) Sterman, J. D., Business Dynamics Systems Thinking and Modeling for a Complex World, Irwin McGraw-Hill, NewYork, USA, (2000).

(12) van der Heijden, K., Scenarios: The Art of Strategic Conversation, John Wiley and Sons. Ltd, Chichester, UK, (2005).

(13) Robinson, J., "Futures under Glass: A Recipe for People Who Hate to Predict," Futures, Vol. 22, No. 8, (1990), pp. 820-842.

(14) Quist, J. and Vergragt, P., "Past and Future of Backcasting: the Shift to Stakeholder Participation and a Proposal for Methodological Framework," Futures, Vol. 38, No. 9, (2006), pp.1027-1045.

(15) Mander, S.L., Bows, A., Anderson, K.L., Shackley, S., Agnolucci, P. and Ekins, P., "The Tyndall Decarbonisation Scenarios-Part I: Development of a Backcasting Methodology with Stakeholder Participation,” Energy Policy, Vol. 36, No. 10, (2008), pp.3754-3763.

(16) Kok, K., van Vliet, M., Bärlund, I., Dubel, A. and Sendzimir, J., "Combining Participative Backcasting and Exploratory Scenario Development: Experiences from the SCENES project,” Technological Forecasting and Social Change, Vol. 78, No. 5, (2011), pp. 835-851.

(17) Alcamo, J., “Scenarios as Tools for International Environmental Assessments,” Ribeiro, T. (ed.), Environmental Issue Report, No. 24, European Environmental Agency, Copenhagen, Denmark, (2001).

(18) Marya, W.H. and Judith, K. S., PRESENTATIONS FOR DECISION MAKERS Third Edition, John Wiley and Sons. Ltd, Chichester, UK, (1996).

(19) Inoue, Y., Kishita, Y., Fukushige, S., Kobayashi, H., Umeda, Y., "Resource Risks of Copper in Sustainability Scenario," Proceedings of EcoDesign 2011: 7th International Symposium on Environmentally Conscious Design and Inverse Manufacturing, A3-08, Kyoto, Japan, Nov. 30-Dec. 2, (2011), pp. 100-104. 